\title{
Phytochemical and Proximate Evaluation of Myrianthus Arboreus (P.Beau.) And Spargonophorus Sporgonophora (Linn.) Leaves
}

\author{
${ }^{1}$ Oyeyemi S. D., ${ }^{2}$ Arowosegbe. S., ${ }^{2}$ Adebiyi A. O \\ Department of Plant Science, Ekiti State University, Ado-Ekiti, Nigeria
}

\begin{abstract}
This study was carried out to investigate the proximate and phytochemical constituents of young leaves of Myrianthus arboreus and Spargonophorus sporgonophora. The result of the proximate analysis revealed that M. arboreus leaves contained moisture content of $40.10 \pm 0.14 \%$, crude fat of $6.45 \pm 0.18 \%$, ash of $3.30 \pm 0.16$, protein of $3.56 \pm 0.10 \%$, Crude fibre of $3.74 \pm 0.14 \%$, dry matter of $70.30 \pm 0.57 \%$ and carbohydrate of $12.58 \pm 0.10 \%$ while S._sporgonophora_leaves contain moisture content $(3.20 \pm 0.84 \%)$, Crude Fat $(6.01 \pm$

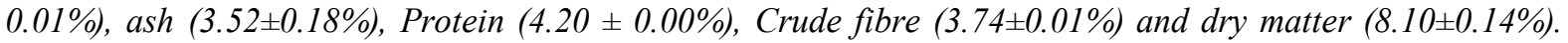
Results of the mineral analysis showed that their leaves contained high concentrations of Calcium, Sodium, Iron and Potassium. Phytochemical screening showed the presence of alkanoids, flavonoids, Tannins and Glycosides. Concentrations of flavonoids and alkanoids were high in the two species. Saponins were absent in M. arboreus while phenols was not found in S. sporgonophora. The results of this study indicated that these local vegetables contained mineral elements and secondary metabolites that are good sources of nutrients for human diet and therapeutic uses.
\end{abstract}

Key words: Phytochemical constituents, therapeutic, proximate analysis, Myrianthus arboreus, Spargonophorus sporgonophora.

\section{Introduction}

Green leafy vegetables play a vital role in the food culture of people in Nigeria and Africa as a whole (1). They are the cheapest and most valuable sources of nutrients such as minerals salts, vitamins, essential fatty acids and fibre which are usually found in daily diets (2). They have the cheapest and most abundant sources of protein (3). A previous study by (4) reported that vegetables are not only cheap sources of nutrients but are also the common sources.

Recently, in Nigeria, there has been an increase interest and awareness in consumption of wild vegetables such as Solanum nigrum, Colocasssia esculenta, Bidens pinnata, Cerathoteca sesamoides, Gongronema latifolium, Cnidoscolus chayamansa and Scenecio biafrae. Most of these traditional vegetables are eaten in the rural areas or in the communities where they are being planted or commonly found. These vegetables are underutilized when compared to the common varieties due to the fact that little knowledge was known and documented about the nutritional and medicinal importance of these vegetables (per. Comm.). Myrianthus arboreus belongs to the family Moraceae. It is a monoecious forest re-growth tree up to $15 \mathrm{~m}$ high with a characteristic false fruit which is yellow when ripe. Leaves are very large, alternately shaped, digitately 5-7 foliolate. Young leaves are usually red in colour. Male inflorescences are yellow, branched and produced panicle like axillary pairs towards later part of the dry season. The female inflorescences are paired, stalked, greenish clusters (pendunculate). Fruit is syncarpous and basally fused, yellow drupes up to $10 \mathrm{~cm}$ with stylar remains projecting from each drupe. The leaves are used in preparation to treat dysentery, diarrhea and vomiting. In eastern Nigeria plaster made of beaten leaf are applied to boil (5). Chopped leaves are eaten raw with salt for heart problems and pregnancy complications. Sap from the leaves is applied tropically for toothache, to the chest for bronchitis or for sore throat (6). Spargonophorus sporgonophora belongs to the family Asteraceae. It is a culinary herb in most African countries. The leaves are boiled in water, drained completely and added to soup or consumed as a vegetable. It is also widely used medicinally in a number of countries. Information is however scanty on the nutritional and phytochemical contents of these local vegetables. Hence there is need to evaluate the nutritional and phytochemical compositions of these uncommonly consumed vegetables.

\section{Materials and Method}

The young shoots of the two indigenous vegetables (M. arboreus and S. sporgonophora) were collected from a farmland in Iyin-Ekiti, Ekiti State, Nigeria in the month of February, 2014. The leaves were separated from the stalk, washed through in distilled water and air dried in the laboratory for three weeks. They were later milled into powders using electric blender. The powdered samples obtained were stored in plastic bottles at ambient temperature until when needed for use. 


\section{Chemical analysis}

The proximate analysis were carried out in duplicates and the data presented were the average value. The estimation of moisture, ash, crude fat and crude fibre were determined in accordance with the official method of (7). The moisture content was determined by drying at $105^{\circ} \mathrm{C}$ in an ovum until a constant weight was reached. For total ash determination, the plant samples were weighed and converted to dry ash in a muffle furnace at $450^{\circ} \mathrm{C}$ and at $550^{\circ} \mathrm{C}$ for incineration. The crude fat content was determined by extraction with hexane, using Soxhlet's apparatus. Carbohydrate was determined by calculating the difference between the sums of all the proximate composition from 100 percentages. Kjeldahl method (8) and the percent of nitrogen value were converted to protein by multiplying with a factor of 6.25. Crude lipid content of the samples was determined using Soxhlet type of direct solvent extraction method. The solvent used was petroleum ether.

\section{Mineral Analysis}

Elemental analyses were carried out using an atomic absorption spectrophotometer and a flame photometer to determine Calcium, Sodium, Potassium and Magnesium contents. The data obtained in parts per million (p.p.m) was converted to $\mathrm{mg} / \mathrm{g}$. Aluminum, Iron and Phosphorus were determined calorimetrically.

\section{Phytochemical Screening}

Phytochemical screening were carried out by adopting were the procedures used in the previous work on plant analysis (9). This analysis determines qualitative and quantitative composition of secondary metabolites such as flavonoids, alkanoids, saponins, phenols and glycosides in the plant species.

\section{Results and Discussion}

Table1. Proximate composition of M. arboreus and S. sporgonophora leaves

\begin{tabular}{lll}
\hline & Percentage composition (\%) & \\
\hline Compositions & M. arboreus & S. sporgonophora \\
\hline Protein & $4.20 \pm 0.00$ & $3.56 \pm 0.10$ \\
Crude fat/lipid & $6.01 \pm 0.10$ & $6.45 \pm 0.18$ \\
Crude fibre & $4.71 \pm 0.00$ & $3.74 \pm 0.14$ \\
Moisture content & $35.20 \pm 0.84$ & $40.10 \pm 0.14$ \\
Ash content & $3.52 \pm 0.18$ & $3.30 \pm 0.16$ \\
Carbohydrate & $7.20 \pm 0.14$ & $12.58 \pm 0.01$ \\
Dry matter & $8.10 \pm 0.14$ & $70.30 \pm 0.57$ \\
\hline
\end{tabular}

Values are mean \pm Standard Deviation of three replicate determinations

Table 2. Mineral composition of M. arboreus and S. sporgonophora leaves

\begin{tabular}{lll}
\hline & Content $(\mathbf{m g} / \mathbf{1 0 0 g})$ & S. sporgonophora \\
\hline Mineral content & M. arboreus & $81.90 \pm 8.62$ \\
Calcium & $90.08 \pm 0.60$ & $3.90 \pm 0.28$ \\
Magnesium & $2.68 \pm 0.17$ & $15.83 \pm 0.53$ \\
Sodium & $17.95 \pm 0.07$ & $53.64 \pm 1.88$ \\
Potassium & $70.62 \pm 0.39$ & $10.58 \pm 0.11$ \\
Iron & $7.44 \pm 0.15$ & \\
\hline
\end{tabular}

Values are mean \pm Standard Deviation of three replicate determinations

Table 3. Qualitative phytohemical analysis of M. arboreus and S. sporgonophora leaves

\begin{tabular}{|c|c|c|c|c|c|c|}
\hline & Flavonoids & Alkanoids & Saponins & Tannins & Phenols & Glycosides \\
\hline M. arboreus & + & + & & + & + & + \\
\hline S. sporgonophorus & + & + & + & + & & + \\
\hline
\end{tabular}

Table 4. Quantitave phytochemical analysis of M. arboreus and S. sporgonophora leaves

\begin{tabular}{lllllll}
\hline & Flavonoids & Alkanoids & Saponins & Tannins & Phenols & Glycosides \\
\hline M. arboreus & $45.62 \pm 0.07$ & $40.56 \pm 0.05$ & $0.00 \pm 0.00$ & $6.88 \pm 0.02$ & $7.02 \pm 0.02$ & $4.60 \pm 0.01$ \\
S. sporgonophorus & $48.55 \pm 0.07$ & $43.27 \pm 0.41$ & $4.45 \pm 0.01$ & $5.35 \pm 0.06$ & $0.00 \pm 0.00$ & $1.00 \pm 0.00$ \\
\hline
\end{tabular}

Values are mean \pm Standard Deviation of three replicate determinations

The results of the proximate, mineral and phytochemical compositions of the leafy vegetables used in this study are as shown in Tables 1, 2, 3 and 4. The protein content of the leaves of M. arboreus and S. sporgonophora was $4.20 \%$ and $3.56 \%$ respectively. These values were lower than that reported by (10) for some other leafy vegetables commonly consumed in Nigeria like Brassica oleracea (11.67\%) and Launnea taraxacifolia (17.64\%). However, results can compare favourably with values in other traditionally consumed vegetables such as Cnidoscolus aconitifolina (2.96\%), Solanum nigrum (3.10\%), Crassocephalum crepidiodes $(1.76 \%)$ and Colocassia esculenta (2.67\%) (11). Also, the result obtained for protein content is similar to the report of (12) who gave the crude protein values for Solanum nodiflora, Senecio biafrae and Cnidoscolus 
chayamansa as $3.03 \%, 3.03 \%$ and $5.91 \%$ respectively. The crude fibre content values obtained were higher than the values reported for Manihot esculenta (3.73\%), Colocassia esculenta (3.30\%), Cerathotera sesamoides $(2.93 \%)$ and Biden pinnata (3.27\%) (11). Crude fibre content of $1.9 \%$ was recorded for Cnidoscolus chayamansa (13) which was lower than the values obtained in this study. Dietry fibre helps to prevent constipation, gastrointestinal disorder, pile, diabetes and breast cancer $(15,16)$. The values of the crude fat for the leaves of M. arboreus $(6.01 \%)$ and S. sporgonophora $(6.45 \%)$ were moderate when compared to those of Talinum triangulare (5.90\%), Baseila alba (3.71\%), Amaranthus hybridus (4.80\%) and Calchorus africanum $(4.20 \%)(17,18)$. These values were fairly high when compared with values reported in some other leafy vegetables such as Ocimum bassillium, Ocimum viride and Piper guineensis (19) hence the consumption of M. arboreus and S. sporgonophora could prevent constipation, gastrointestinal disorders and other ailments. The leaves of the vegetables in this study contained $6.45 \%$ and $6.01 \%$ crude lipid respectively (Table1) which are lower than the values reported for Baseila alba $(8.71 \%)$ but higher than the values reported for Talinum triangulare (5.90\%), Amaranthus hybridus (4.80\%) and Calchorus africanum $(4.20 \%)(17,18)$. The moderate amount of fat in the leaves shows that the vegetables are not source of lipid accumulation. Crude lipids, though serves as principal sources of energy should be consumed with caution so as to avoid obesity and other related diseases (20). The carbohydrate content of the leaves was within the range of $(1.22 \%-15.90 \%)$ reported for some selected Nigerian leafy vegetables (21). The values obtained in this study fell below carbohydrate values for Momordica balsamina (39.05\%). The carbohydrate content of the leaves of M. arboreus $(7.20 \%)$ and S. sporgonophora $(12.58 \%)$ were considerably low compare to some leafy vegetables like Tribulus terrestris "Tsaida" and Corchorus tridens (22). Ash content of the two leafy vegetables was lower than that reported for Diplazium summattii (Nyama idim) (23) and those of Tridax procumbens (24). The knowledge of ash content gives an indication of the mineral composition of the leaves. The two vegetables investigated had higher moisture content of $35.20 \%$ and $40.10 \%$ respectively. The moisture content was lower than those reported for some other vegetables grown in South west, Nigeria like: Lannea taraxacifolia $(79.77 \%)$, Ocimum gratissium $(83.87 \%)$, Vernonia amygdalina $(78.60 \%)$ and Biden pinnata $(85.53 \%)(11)$. However, the values were comparatively higher than those values reported for vegetables like Moringa oleifera (5.9\%) (25) and Hippocratea myriantha (6.93\%). The moisture content of food is used as a measure of stability and susceptibility to microbial contamination (26). The high moisture content found in the leaves of plants in this study agreed with the report that water is the most abundant component in all vegetables (27). The results of mineral analysis of the vegetable leaves (Table 2) indicated that the minerals detected were calcium, potassium, magnesium, sodium and iron. The leaves of S. sporgonophora and M. arboreus showed high level of Calcium for sustaining strong bones, muscular contraction and relaxation, blood clothing and absorption of vitamins $\mathrm{B}_{12}(1,28)$. These values could be said to be low since the values can only contribute about $6.83 \%$ and $7.51 \%$ respectively to the Recommended Daily Allowance (RDA) values of Calcium for an adult man with 300kcal/day whose recommended energy intake is $120 \mathrm{mg}(29,30,31)$. The Potassium content were higher than the values found in Cnidoscoius chayamansa (4.02\%), Solanum nodiflorum $(0.19 \%)$ and Solanum biafrae $(0.18 \%)(12)$ and also values reported for Amaranthus hybridus leaves (32). The leaves of S. sporgonophora can contribute about $4.00 \%$ to RDA of the Recommended Daily Allowance (RDA) of Potassium which is $200 \mathrm{mg}$ for adults (29). The value obtained for Sodium is lower compare with the previous values reported for some selected Nigerian vegetable leaves (21). Sodium and Potassium are important intracellular and extracellular cations respectively. The importance of NA/K ratio in the body in controlling high blood pressure cannot be over emphasized (33). The result of Iron content of M. arboreus was $7.44 \mathrm{mg} / 100 \mathrm{~g}$ which was lower than the value found in Ocimum viridis and Ocimum gratissimum (34). Iron content of S. sporgonophora was $10.58 \mathrm{~g} / 100 \mathrm{mg}$ which is high when compared with the value obtained for Tribulus terrestris "Tsada" and in some cultivated vegetables such as spinach, lettuce and cabbage but compared favourably with values found in Mucuna poggei $(10.58 \mathrm{mg} / 100 \mathrm{~g})$ (20) and Ocimum gratissimum (10.32mg/100g) (34). Green vegetables are recommended for anemic convalescence. The value for iron in the leaves though lower when compared with RDA (mg/day) could help in boosting the blood level in anemic conditions (29). The Magnesium content of the leaves were $2.68 \mathrm{mg} / 100 \mathrm{~g}$ and $3.90 \mathrm{mg} / 100 \mathrm{~g}$ respectively which are higher than the values reported for C. chayamansa, S. nodiflorum and S. biafrae but lower than that reported for bitter leaf (V. amygdalina) $(61.08 \mathrm{mg} / 100 \mathrm{~g})$, Basella alba $(92.51 \mathrm{mg} / 100 \mathrm{~g})$, Hibiscus sabdariffa $(120 \mathrm{mg} / 100 \mathrm{~g})(21)$. The magnesium content in the samples investigated was lower when compared with RDA for magnesium in adult which is $350 \mathrm{mg} /$ day (29).

The phytochemical screening of the leaves of M. arboreus and S. sporgonophora (Table 3) showed that the leaves of the two samples contained flavonoids, alkanoids, tannins and cardiac glycoside. The presence of these phytochemical could have been responsible for their medicinal values as well as physiological activities (34). High concentration of flavonoids and alkanoids were recorded in both samples while concentrations of saponins and tannins are moderate in the leaves of plants investigated (Table 4). Flavonoids are widely distributed in plants fulfilling various functions. They have been reported to have antibacterial, antiinflammatory, antiallegic, antimutagenic, antiviral, antithrombotic and vasolidatory activity (35). Alkanoids, 
nitrogen-containing compound are commonly found to have antibacterial properties due to their ability to intercalate with DNA of the microorganisms (37). (38) reported that alkanoids are powerful pain relievers, have an antipyretic action, a stimulating effect and can act as tropical anesthetic in ophthalmology. Saponins were found in S. sporgonophora but absent in M. arboreus leaves. Presence of saponins had been reported to possess both beneficial and deleterious properties. $(39,40)$. The presence of Tannins in the leaves also agreed with the previous works of $(11,41)$ and $(34)$ who also discovered traces of tannins in some leafy vegetables grown and consumed in Nigeria. Tannins are known to have antiviral, antibacterial and anti-tumor properties. Tannins can also be effective in curbing hemorrhages as well as restrict bare swellings. When applied internally, tannins affect the walls of the stomach and contract or squeeze the membranes in such a manner that secretions from the cells are restricted. Long term and / or excessive use of herbs/ vegetables with high concentration of tannins are not advisable (42). Hence, vegetables with moderate concentration of tannins is good for human health $(1,28)$. Phenols were present in M. arboreus and absent in S. sporgonophora leaves. Phenols are strong antioxidants and play a role in the prevention and management of chronic diseases such as cancer and cardiovascular disease. (43) reported that plant phenols may interfere with all stages of the cancer process resulting to reduction of cancer risk.

\section{Conclusion}

This study has provided useful biochemical information on nutrition and phytochemical compositions of M. arboreus and S. sporgonophora leaves. The results obtained revealed that M. arboreus and S. sporgonophora which are local and underutilized vegetables have appreciable amounts of nutrients such as calcium, potassium, iron, protein and anti-nutrients. This suggests that the indigenous leafy vegetables may serve as a constituent of human diet supplying the body with minerals, protein and energy for normal growth. The presence of phytochemical also contributes to their medicinal potentials.

\section{References}

[1]. Mensah, J.K., Okoli, R.I. and Ohaju-Obodo, J.O. (2008). Phytochemical, medicinal and nutritional properties of some green leafy vegetables. Afr. J. Biotechnol.2512 (12), 758

[2]. Tukan, S.K., Takruri, H.R. and Al-Eisaw, D.M. (1998). The use of wild edible plants in the Jordanian diet. International Journal of Food Science and Nutrition, 49, 225-235.

[3]. Fasuyi, A.O. (2006). Nutritional potential of some tropical vegetable leaf meals. Chemical characteristics and functional properties. Afr. J. Biotechnol. 5(1): 49-53.

[4]. Okafor, J.C. (1983). Horticulturally promising indigenous wild plants species of the Nigerian Forest Zones. Acts Horticulture. $123,165-177$.

[5]. Okafor, J.C. (2004). Myrianthus arboreus P.Beauv. In: Grubben. G.J.H. Dentron. O.A (Editors) PROTA 2: Vegetation / Legumes (CD ROM). PROTA Wagehingen. Netherlands.

[6]. Agwa, O.K; Chukwu, W. and Obichi, E.A. (2011). The invitro effect of Myrianthus arboreus leaf extract on some pathogenic bacteria of clinical origin. J. Microbial. Biotech. Res. 1(4): 77-85.

[7]. AOAC (1990). Official method of Analysis. (15th ed.). Association Official Analysis Chemists. Washington DC.

[8]. Pearcon, D. (1976). Chemical analysis of food, 7th edition. Churchill, London, 7-11.

[9]. Odebiyi, O.O. and Sofowora, E.A. (1979). Phytochemical screening of Nigerian Medicinal plants 2nd OAU/ STRC Inter-African Symposium on Traditional Pharmaco Poeia and African Medicinal Plants (Lagos) No, 115: 216-220.

[10]. Emebu, P.K. and Anyika, J.U. (2011). Proximate and Mineral composition of Kale (Brassica oleracea) grown in Delta State, Nigeria. Parkistan Journal of Nutrition. 10(2): 190-194. (3).

[11]. Oduse, K.A; Idowu, M.A. and Adegite, A.A. (2012). Chemical and phytochemical profile of some uncommon green leafy vegetables consumed in South West, Nigeria.

[12]. Adeleke, R.O. and Abiodun, A.O. (2010). Chemical composition of Three Traditional Vegetables in Nigeria. Pakistan Journal of Nutrition (9): 858-860.

[13]. Kuti, J.O.and Torres, E.S. (1996). Potential nutritional and health benefits of tree spinach. In: J. Janick (Ed.) Progress in new crops. ASHS Press. Arlington, V.A, pp: 516-520.

[14]. Latunde-Dada, G.O. (1990). Effect of processing on iron level and availability from Nigeria vegetables. J. Sc. Food Agric. 53: 355-361.

[15]. Rao, C.V. and Newmark, H.L. (1998). Chemo- preventive effect of squalene on colon cancer. Carcinogenesis, 19, 287-290.

[16]. Ishida, H; Suzuno, H; Sugiyama, N; Innami, S; Tokodoro, T. and Maekawa, A. (2000). Nutritional Evaluation of chemical component of Leaves and stems of Sweet Potatoes (Ipomoea batata poiv). Food Chemistry. 68, 359-367.

[17]. Ifon, E.I. and Bassir, O. (1979). The nutritive value of some Nigeria leafy green vegetables part 2. Distribution of protein, Carbohydrate, Fat. J. Food Chem; 5: 231-235.

[18]. Akindahunsi, A.A. and Salawu, S.O. (2005). Phytochemical Screening and nutrient- antinutrient composition of selected tropical green leafy vegetables. Afri. J. Biotech., 4: 497-501.

[19]. Udosen, E.O. (1995). Proximate and mineral composition of some Nigerian Vegetables. Discov. Inov., 7, $383-386$.

[20]. Oko, A.O. (2012). Nutritional and phytochemical composition of Leaves of Mucuna poggei. Journal of Biology and Life Science. Vol. 3, No.1: 232-242.

[21]. Asaolu, S.S; Adefemi, O.S; Oyakilome, I.G; Ajibola, K.E.and Asaolu, M.F. (2012). Proximate and Mineral Composition of Nigerian Leafy Vegetables. Journal of Food Researh; Vol.1, No.3:214-218.

[22]. Asibey-Berko, E. and Tayei, F.A.K. (1999). Proximate analysis of some atilized Ghanaian vegetables. Ghana Journal of Science, 39, 91-92.

[23]. Osabor, V.N; Egbung, G.E.and Ntuk, U.M. (2010). Chemical Evaluation of the leaves of Diplazium summattii (Nyama idim). Research Journal of Agriculture and Biological Sciences, 6(6): 1074-1077. 
[24]. Ikewuchi, C; Ikewuchi, C.C. and Ighoh, M.N. (2009). Chemical profile of Tridax procumbens linn. Pakistan Journal of Nutrition, 8(5): 548-550.

[25]. Yameogo, C.W., Bengaly, M.D., Savadogo, A., Nikiema, P.A and Traore, S.A. (2011). Determination of chemical composition and nutritional values Moringa oleifera leaves. Par. J. Nutr, 10: 264-268.

[26]. Uraih, N. and Izuagbe, Y. (1990). Public health food and Industrial microbiology, Benin, Uniben Press, Nigeria.

[27]. Fayemi, P.O. (1999). Nigerian vegetables. (Heins educational book, Ibadan, Nigeria.

[28]. Lewis, W.M. and Elvin-Lewis, M. P. F. (1998). The use of wild edible plants in the Jordanian diet. International Journal of Food Science and Nutrition, 49,225-235.

[29]. NRC (1989). Recommended Dietry allowance. National Research Council. National Academy Press, Washington, DC.

[30]. Dosumu, M.I. (1997). Chemical composition of the Fruit of Tetraptera and the Physico- chemical properties of its oil. Global Journal of Pure and Applied Science, 3, 61-67.

[31]. Turan, M; Kordis, S; Zeyin, H; Dursan, A. and Sesen, Y. (2003). Macro and micro minerals content in some Wild Edible Leaves consumed in Eastern Anatolia. Tailors and Francis, 129-130.

[32]. Nwaogu, L.A; Ujuwundu, C.O. and Mgbemana, A.J. (2000). Studies of the nutritional and phytochemical composition Amarathus hybridus leaves. Bis. Res, 4, 28-31

[33]. Yusuf, A.A; Mofia, B.M. and Ahmed, A.B. (2007). Proximate and Minerals Composition of Tamarindus indica linn 1753 seeds. Science World Journal, 2, 1-4

[34]. Abdurahman, F.I; Tijani, M.A. and Osuyi, U.O. (2012). Proximate content and chemical composition of Ocimum viridis leaf and Ocimum gratissium leaf. IRJP, 2(3): 347- 354.

[35]. Sofowora, E.A. (1996). Medicinal plants and traditional medicine in Africa. Spectrum Books Ltd. Ibadan, 55-71.

[36]. Alan, L. and Miller, N.D. (1996). Antioxidant Flavonoids: Structure, Function and Clinical Usage Alt. Med. Rev., 1:103-111.

[37]. Kasolo, J.N; Gabriel, L.O; Bimeya, O; Joseph, O. and Ogwal-Okeng, J.W. (2010). Phytochemical and uses of Moringa oleifera leaves in Ugandan rural communities. J. Med. Plants Res., 4(9): 753-757.

[38]. Edeoga, P.K. and Enata, D.O. (2011). Alkanoids, Tannins and Saponin content of the medicinal plants. J. Med. Amn. Plant Sci., 23: $344-349$

[39]. Prince, K.R., Johnson, I.T. and Fenwich, G.R. (1987). The chemical and biological significance of saponins in food and feedstuffs. CRC. Crit. Rev. Food Sci, Nutri., 26: 27- 135.

[40]. Oakenful, D. and Sidhu, G.S. (1989). Saponins. In: Cheeke, P.R. (Ed.), Toxicants of plant Origin. Academic Press New York 2: 78113.

[41]. Bamishaiye, E.I., Olayemi, F.F., Awagu, E.F., Bamishaiye, O.M. (2012). Proximate and Phytochemical Composition of Moringa oleifera Leaves at three stages of maturation. Advance Journal of Food Science and Technology, 3(4): 233-237.

[42]. Reed, J.D. (1995). Nutritional toxicology of tannins and related polyphenols in forage legumes. J. Anim. Sci., 73(5): 1516-1528.

[43]. Holland, P.C. (2001). Evidence for health benefits of plant phenols: Local or systemic effects? J. Sci. Food Agric, 81, $842-852$. 